\title{
CONTROVERSY IN HISTORY EDUCATION: EXPERIENCES OF JAPAN AND INDONESIA
}

\author{
Singgih Tri Sulistiyono *
}

\begin{abstract}
Abstrak
Tulisan ini mencoba untuk membandingkan kontroversi sejarah yang terjadi di Jepang dan di Indonesia. Meskipun kedua negara ini memiliki masalah yang sama dalam kaitannya dengan kontroversi penulisan dan pengajaran sejarah, namun ada beberapa aspek yang berbeda. Kontroversi sejarah Jepang terkait dengan negara-negara tentangga khusunya Korea dan Cina dalam kaitannya dengan kekejamankekejaman Jepang selama Perang Dunia, sedangkan kontroversi sejarah dan pembelajaran sejarah di Indonesia terkait dengan masalah internal bangsa khususnya yang berhubungan dengan peristiwa Gerakan 3 September tahun 1965. Tulisan ini akan menganalisis pengalaman kedua negara tersebut dalam menangani kontroversi tersebut dan termasuk di dalamnya pengalaman guru dan murid.
\end{abstract}

\section{Keywords: Controversy, History Education, Historical Fact.}

\section{Introduction}

The important of Japan in the current developing world cannot only be measured by its significant position in the field of economy, politics, cultural, science and technology, but also its development in history teaching at school. The significance of study concerning history teaching in Japan does not mainly lie on the Japanese successful to cultivate historical values to the school students, but it lies on the emerging discourses reflecting a bitter struggle among three elements in the history education at school, i.e. historical truth, political interest, pedagogical and moral value.

History teaching at Japanese schools has developed through a long and complicated process during the course of its history. Even until now the history teaching in this 'sakura' country is still provoking controversies not only domestically

*Singgih Tri Sulistiyono, Lecturer of Department of History, Faculty of Letters, Diponegoro University. Chairman of Central Java Branch of Indonesian Historian Association (2006-2010), 
but also regionally and even internationally. In the regional and international level, the controversies had been emerged by countries and/ or societies who in the past became the subject of Japanese expansion, colonization, and atrocities. The protest is mainly proposed by China and Korea. They accuse Japanese government had manipulated, distorted, and falsified historical facts in connection with atrocities done by Japanese soldiers during its imperialistic expansion following the modernization since Meiji Restoration. China and Korea demand the Japanese government to write history as it actually happened', especially if it is relating with Japanese aggressions onto these countries. ${ }^{1}$

Controversies of history teaching are also experienced by Indonesia. Different from Japanese case, controversies in Indonesian history does not have close connection with neighboring countries as experienced by Japan. Even it can be said that controversies in history teaching at school in Indonesia is more an internal problem rather than external one. This paper is intending to compare the controversies of history teaching in Japan (especially at lower secon-dary school) and those in Indonesia and the responses both governments to the controversies. Besides, the paper also intends to survey the way history teacher teach controversial teaching material to the students.teaching material to the students.

\section{Education in Japan}

\section{Modernization}

The modern schooling system in Japan had actually been started since the Meiji Restoration in 1868, when the new Japanese leadership drove this country in a rapid motion for modernization. Motivated by the strength of the western power (especially America) who had succeeded to open 'Japanese political isolation ' by force, the Japanese rulers immediately took steps to modernize the country for catching up with the West and forming a modern nation by adopting new educational system from the Westerns. Missions like the Iwakura mission were sent abroad to study the education systems of leading Western countries. ${ }^{2}$

Only in a short time the world,

${ }^{1}$ These words has ever been stated by Leopold von Ranke, positivist historian from Germany, see Raymond Aron, 'Relativism in History', in: Hans Meyerhoff, The Philosophy of History in Our Time: An Anthology (New York: Anchor Original Publisher, 1959), 153.

2 The mission was headed by Iwakura Tomomi assisted by 53 people. In addition to the mission staffs, about 60 students were brought along. Several of them were left behind to complete their education in the foreign countries, including five young women who stayed in U.S.A. to study. On December 23, 1871 the mission sailed from Yokohama, bound for San Francisco. From there it continued to Washington, D.C., then to Britain, France, Belgium, the Netherlands, Russia, Prussia, Germany, Denmark, Sweden, Austria, Italy, and Switzerland. On the return journey, Egypt, Aden, Ceylon, Singapore, Saigon, Hong Kong, and Shanghai were also visited, although much more briefly. The mission returned home September 13, 1873, almost two years after setting out. See 'Iwakura Mission', in: http://en.wikipedia.org/wiki/Iwakura mission (visited on 30 May 2007). 
Japanese government succeeded to implement new education system and attracted public to send their children at school. In 1900, more than 90 percent of the school age population enrolled to elementary schools. Until the recent, Japan has one of the highest standards of education and one of the highest literacy rates in the world. About 93\% of children enter high school, and nearly all of them graduate. At over $40 \%$ in 2000 , Japan also has one of the highest university enrolment rates in the developed world, and a huge number of state and private universities to serve the population. ${ }^{3}$

\section{General Objectives}

The main objective of education (especially at lower secondary school) is to help students acquire essential knowledge, skills and mind to have healthy social life as an individual as well as a member of the society/nation. It also aims at helping student foster rich humanity, recognize and develop their individualities and further cultivate mind of self-reliance. ${ }^{4}$

Generally speaking education in Japan is very futuristic and is functioned to anticipate the rapid change occurring in the $21^{\text {st }}$ century both domestically and internationally. The spirit of the curriculum is to help children for cultivating their well-balanced development and is for educating them to be sound members of the nation and the society living independently in the 21st century. However, it is not only the solely task of school but the cooperation with family and society is also needed. Schools, families and communities must cooperate and effectively demonstrate their individual educational function.

\section{Social, National, and International Contexts}

The objectives of education are not only giving stress on cultivating individual capabilities, but also cultivating well-balanced rich humanity and sociality. Rich Humanity includes sympathy, mind to respect each other and live together in harmony, respect for life and human rights, sensibility of appreciating beauty and the environment, volunteer spirit, mind to make efforts to achieve one's own goal and the like. High value will be set on moral education which helps children acquire social rules and basic morality, a sense of norms, public morals, justice and fairness, sound judgment, strong will and ability to take action, awareness of responsibility, autonomy, self-control and the like. In addition, children's healthy development and physical strength are also emphasized for them to lead vigorous lives.

\footnotetext{
May 2007)

${ }^{3}$ See `History of Education in Japan`, in: http://en.wikipedia.org/wiki/History_of_Education_in_Japan (visited on 30

${ }^{4}$ The Curriculum Council, 'Synopsis of the Report National Curriculum Standards Reform for Kindergarten, Elementary School, Lower and Upper secondary School and Schools for the Visually Disabled, the Hearing Impaired and the Otherwise Disabled', in: http://www.mext.go. jp/english/news/1998/07/980712.htm
} 
Children will be encouraged to deepen their understanding of national as well as local history, culture and tradition, and to develop love to those matters. They will also be encouraged to appreciate different cultures open-mindedly, and to cultivate the mind of international cooperation and the identity as Japanese living in the international community. Current problems which are faced by Japanese society also become the basic material to be studied by lower secondary school such as those of the impacts of internationalization and globalization, the increasing critical issues on environment, the ongoing process of aging society with declining birthrate in Japan, etc. In short, the students are prepared to be responsive against present and future human problems both locally and globally.

In respect with tendency for school education to emphasize volumes of knowledge for forcedly creating an intellectually genius man, education in Japan is now tending to be in a position in which the school education looks itself from the children's standpoint and places a high value on the development of children's intellectual interests and inquiring minds. Thus, the school education positively conducts its activities by emphasizing the importance of motivating children to learn by themselves and helping them develop abilities to learn, reason, judge, express themselves accurately, discover and solve problems, acquire basic creativity and act independently in response to social changes. Additionally, children are encouraged to use their knowledge and skills comprehensively in daily life in order to successfully relate their knowledge acquired at school with the actual life. This requires the promotion of such educational activities as hands-on learning activities, problem-solving activities and activities to teach how to research and how to learn.

In connection with the ongoing rapid social changes, schools in Japan are preparing student to anticipate it well. First of all, the school education helps children securely acquire the "absolute value in all ages" in this kaleidoscopic world. Besides, school education helps children developability to anticipate social changes and to cope with them flexibly.

\section{Curriculum}

Curriculum as a set of courses offerings to the student should ideally be based on the philosophical basis and objective of education in general. Based on the objectives of education at lower secondary school, the national curriculum standard will be shortly outlined bellow. In this case the government also gives a broader opportunity to school to show ingenuity in developing the institution to be distinctive school institution especially in respect to develop what the so called 'Integrated Study'. In general, contain of national curriculum standard at lowersecondary school includes Japanese language, social studies, geography, history, civics, arithmetic, mathema- 
tics, science, life environment studies, music fine arts, crafts, calligraphy, homemaking industrial art and home economics, health and physical education, foreign language, information studies, subject areas (professional education), moral education, and special activities. ${ }^{5}$

In the subject of social studies, geography and history and civics, the emphasis is given on the development of children's capabilities required as Japanese in the international society. The capabilities include mind and ability to study both domestic and international incidents from various angles and then to make judgments in a fair fashion, understanding and love of their country and its history, and the spirit of international cooperation. Thus, schools will encourage students to learn how to study and research and to participate in hands-on learning activities and problem-solving activities, rather than placing too much emphasis on students' knowledge of all matters. In history classes at lower secondary school, students will study Japanese history together with world history as background knowledge. Japanese history will be shown in large sections, so that students can grasp the major flow of the history. The students will also be expected to view things from different angles by learning how to study and examine history. Considering the consistency with lower secondary schools, upper secondary schools will help students deepen their understanding of Japanese and world history and develop their ability to think from a historical point of view. Japanese and world history and develop their ability to think from a historical point of view.

\section{Controversies in History Teaching (Focus on History Textbook)}

\section{Early Controversy}

The controversy of Japanese history textbook actually did not firstly rise by other countries such as Korea and China. Long before China and Korea strongly protested against Japanese history textbook in 1982, one of the leading Japanese historians, i.e. Ienaga Saburo did not only protest but he filed lawsuit against Ministry of Education. In 1965 he filed the first of his three lawsuits against the Ministry of Education alleging the Government was unconstitutional in censoring history textbook. Ienaga's history textbook viewed as "too many illustrations of the 'dark side' of the war, such as an air raid, a city left in ruins by the atomic bomb, and disabled veterans." His second suit two years later also involved the issue of constitutionality and, in addition, focused on points related to Ienaga's characterization of Japan's foundation

\footnotetext{
${ }^{5}$ Most part of this section is outlined from The Curriculum Council, 'Synopsis of the Report National Curriculum Standards Reform for Kindergarten, Elementary School, Lower and Upper secondary School and Schools for the Visually Disabled, the Hearing Impaired and the Otherwise Disabled', in: $h$ ttp://www.mext.go.jp/english/news/1998/07/980712.htm
} 
myths and a description of the 1941 Japan-USSR neutrality pact. ${ }^{6}$

The third lawsuit in 1984 connected with the 'unconstitutional censoring' of the description on, among others, Nanking Massacre and its sexual assault. ${ }^{7}$

Japanese history textbook began to be a world-wide controversy and called for international debate since the early of the 1980s, when on 26 June 1982 the 'Asahi Shimbun', one of the big three leading national newspapers in Japan, reported that the Ministry of Education demanded a textbook that wrote that the Japanese army 'invaded Northern China to rewrite it to 'advanced into`.

The Chinese and South Korean governments immediately protested to the Japanese government. The content of the Japanese history textbook was viewed as a kind of manipulation in writing history by covering cruelty and atrocity of Japanese invasion into Korea and China before and after the World War I. They also alleged Japan as having no remorse on the war which had caused unvalued destruction. 8 officially made statement that the Japanese Government and the Japanese people are deeply aware of the fact that acts by our country in the past caused tremendous suffering and damage to the peoples of Asian countries, including the Republic of Korea and China, and have followed the path of a pacifist state with remorse and determination that such acts must never be repeated. This kind of statement had actually ever been agreed by Japan, China, and Korea. In 1965, Japan and Korea had ratified a Joint Communiqué that the past relations are regrettable, and Japan feels deep remorse. The same thing was also done saying that is keenly conscious of the responsibility for the serious damage that Japan caused in the past to the Chinese people through war and deeply reproaches itself. In connection with the criticized history textbook, the Japanese government promised to take steps for making correction to the government responsibility in that matter and would revise the Guideline for Textbook Authorization after discussions in the Textbook Authorization and Research Council. Again, the Japanese government stressed to promote mutual understo promote mutual understanding and develop friendly and cooperative relations with neighboring countries and to contribute to the peace and stability of Asia and, in turn, of the world. ${ }^{9}$

\footnotetext{
${ }^{6}$ See Kathleen Woods Masalski, 'Examining the Japanese History Textbook Controversies', in: http://www.indiana.edu/ japan/Digests/textbook.html (Visited on 1 June 2007).

7 See more detail 'Saburo lenaga', in: http://en.wikipedia.org/wiki/lenaga Saburo (Visited on 1 June 2007).

8 The use of term 'advancement' had actually been existed since 1973 when Yamagawa Publishing published revised World History. It was said that 'Japan obtained the clue of the advancement to Korea by making Qing admit the independence of Korea'. See Tomochika Okamoto, 'The Distortion and the Revision of History in Postwar Japanese Textbooks, 1945-1998', in: http://homepage3.nifty.com/ ubiquitous/MA/index original.htm (Visited on 17 April 2007). But at that time this history textbook did not become controversy. Possibly it related with the limited access of information and contextual global political situation.
} 
As a realization of the promise of Japanese government, in November 1982 the Ministry of Education adopted a new authorization criterion, the so-called "Neighboring Country Clause". It was stressed that the history textbooks ought to show understanding and seek international harmony in their treatment of modern and contemporary historical events involving neighboring Asian countries. The result was that history textbook gave more detail about the 'negative side' with a more `naked' word of expression of the Japanese expansion to Korea and Japan. In the revised World History issued by Yamakawa Publishing, it was said for example: 'Postwar Japan aimed at aggression on the continent, and annexed Korea in spite of ardent resistance of the Korean side in 1910 (the annexation of Korea). ${ }^{10}$

In line with the process of trans-nationalism and globalization, the more open policy in writing history textbook in Japan since 1983 had resulted a 'liberal description' on the history of Japan especially in connection with the Japanese policies and actions outside Japan. In one hand this development certainly satisfied neighboring countries which had ever been targeted by Japanese military expansion leading to the absence of protests concerning the military expansion leading to the absence of protests concerning the Japanese history textbook. But on the hand, this kind of history writing raised a certain impact to the Japanese society. Some Japanese scholars who had 'strong' nationalism felt that history had been functioned as the court in which the historical figures of the past are called to be judged.

\section{Ongoing Situation}

A certain degree of opinions differences actually occur among Japanese people including intellectuals, politicians, and other group of professional such as history teachers, etc. Ienaga Saburo is one of historian who tries to tell the past truth as it actually happened, regardless the history readers. But another group of historians who concern with history as a material for instructions especially for school students tend to urge 'positive' events that are told to the student. One of the most prominent leaders of this group is Fujioka Nobukatsu, a professor of education at Tokyo University, who since the end of the 1990s urged the reform of Japanese history curriculum. He set out to "correct history" by emphasizing a "positive view" of Japan's past and by removing from textbooks any reference to matters associated with what he calls "dark history," issues such as the comfort women, that might make Japanese schoolchildren

\footnotetext{
${ }^{9}$ See 'Japanese History Textbook Controversies', in: http://en.wikipedia.org/wiki/ Japanese history textbooks controversy (Visited on 1 June 2007).

${ }^{10}$ See Tomochika Okamoto, 'The Distortion and the Revision of History in Postwar Japanese Textbooks, 1945-1998', in: http://homepage3.nifty.com/ ubiquitous/MA/index original.htm (Visited on 17 April 2007).
} 
uncomfortable when they read about the Pacific War.11

When he was asked by Asia Week concerning the problems faced by Japanese history textbook writing, he said: ${ }^{12}$

Simply that they are not written with Japanese people in mind. They present a history hostile to Japan; the negative view our own socialists and communists and liberal media - the major newspapers, notably Asahi Shimbun, and the networks - have of our country; the U.S. and other Western nations seeing Japan as nothing but an evil aggressor during the war; and the perspective of China and Korea, to whom Japan continually apologizes. The impact on our children is such that they write in their essay classes that Japan is the worst, most immoral country in the world'.

In 2000, Fujioka and his group of conservative scholars established an association called the Japanese Society for History Textbook Reform. This association then published, The New History Textbook. This book was actually only one of eight secondary school history textbooks which were approved by the Ministry of Education in April 2001 and ready to Education in April 2001 and ready to be started in use in 2002 school year. This book has caused huge controversy. Nishio Kanji as the leader of the Society summarized the views of the Society in an article in the August 2001 Japan Echo. The article maintained that the textbook aims to restore common sense to the teaching of the subject. He says that the history teaching should be no more treated like a court in which the figures and actions of the past are called to be judged. ${ }^{13}$

By the end of December 2000, the Society circulated the textbook draft to the school districts and even shown on national television. It is surprisingly that the reaction against the textbook firstly came from Japanese society itself. The reaction even was not only addressed to the textbook for lower secondary school but also continued to some textbooks for upper secondary school during the consecutive years. ${ }^{14} \mathrm{~A}$ series of critical reactions had launched by historians, historians, NGO's, etc, ranging from the end of 2000 until 2005, such those of Children and Textbooks Japan Network 21 together with Committee for Truth and Freedom in Textbooks, Advisory Committee for Discussing Social Studies Textbook Problems, Liaison

\footnotetext{
11 See Kathleen Woods Masalski, 'Examining the Japanese History Textbook Controversies', in: http://www.indiana.edu/ japan/Digests/textbook.html (Visited on 1 June 2007).

12 See 'Let's Stop Apologizing: A Professor’s Battles Outside the Classroom', in: http://www. asiaweek.com/asiaweek/97/0314/nat4.html (Visited on 4 June 2007).

13 Masalski, 'Examining the Japanese History Textbook Controversies', in: http://www.indiana.edu/ japan/Digests/textbook.html (Visited on 1 June 2007). See also 'Japanese History Textbook Controversies', in: http://en.wikipedia.org/wiki/Japanese_history_textbooks_controversy (Visited on 1 June 2007).

${ }^{14}$ See for example Children and Textbooks Japan Network 21, 'Criticisms of the Japanese Government Authorization of Japanese History Textbooks - The Case of Koko Nihonshi B (Senior High School Japanese History Textbook B) Published by Meiseisha' in http://www.ne.jp/asahi/kyokasho/net21/e 020429seomei.htm (Visited on 4 June 2007).
} 
Committee for the Japan Textbook Publishers Union, and Committee for Monitoring Historical Truth, who in 12 September 2000 on-lined an article entitles 'The Falsification of History under the Guide of 'Self Censorship' has been Forced onto Textbook Publishers: We will not Tolerate the Actions of the Government and the Ministry of Education`. This article gave some critics to the textbook produced by Japanese Society for History Textbook Reform and even other seven companies publishing history textbooks that had been approved by the Ministry of Education. There were several points criticized, among others: the so called 'comfort women', Nanjing Massacre, ThreeAll Policy, the Battle of Okinawa, the use of the term 'advance' (shinshitsu) instead of 'invasion`.

Although there had been severe criticism both from Japanese people internally and other Asian neighbors externally, the textbooks remained to be approved by the Ministry of Education. Corrections were actually had been made according with Ministry screening recommendation, but it was viewed by the Children and Textbooks Japan Network 21 (Kodomo to Kyokasho Zenkoku Netto 21) and its groups that the changes were not significant. For that reason the children and Textbooks Japan Network 21 joined with more other associations to challenge the existing textbook condition. The Groups consist of the Children and Textbooks Japan Network 21,
Committee for Truth and Freedom in Textbooks (Kyokasho ni Shinjitsu to Jiyu o Renrakukai), Advisory Committee for Discussing Social Studies Textbook Problems (Shakaika Kyokasho Kondankai Sewaninkai), Japanese Society for Democratic Education (Zenkoku Minshushugi Kyoiku Kenkyukai), Liaison Committee for the Japan Textbook Publisher Union (Nihon Suppan Rodokumiai Rengokai), Center for Research and Documentation on Japan's War Responsibility (Nihon no Senso Sekinin Shiryo Senta), etc.

In 3 April 2001, they declared a joint declaration as a reaction against the textbook sponsored by the Japanese Society for History Textbook Reform. The joint statement, which is published via internet, entitles 'A Textbook that Treads the Path of Constitution Denial and International Isolation Should not be Handed over to Japanese Children`. This joint statement criticized the textbook. There is several points mention in the join statement among other the Greater East-Asian War, comfort women issue, the legend of Emperor Jimmu, the nature Japanese nationalis etc.

In connection with the AsiaPacific War, this join statement criticized that the textbook still refer to such a war as the 'Greater EastAsian War'. According to join statement, this not only fails to recognize the fact that this was a war of invasion, but it also takes a standpoint that glorifies and affirms the war as one fought for Asian liberation. There is no reflection on 
the annexation and colonization of Korea, rather a sense of its justification remains. The fact of the existence of so-called 'comfort women' is completely ignored, and there is only a one-sided account of the Nanjing Massacre from a standpoint of denial.

In connection with the Emperor of Jimmu, the joint statement criticized the way the textbook treated myths as if they were historical facts, while minor corrections were made, there is almost no change in contents or size, e.g., a map of "Legendary Emperor Jimmu's Eastern Expedition" is published as is.

According to the join statement, Japanese history is presented in a way that suggests the authority of the emperor was consistent, while baseless contempt is shown for the history of Asian countries. It seems that the textbook tries to plant pride in a narrowminded Japanese nationalism that bypasses internationalism. Even the join statement interpreted what the Japanese Society for History Textbook Reform as an effort to benefit history education for military purposes. This because in the post-war study of history and historical education, Japan has respected historical facts that were scientifically confirmed. The join statement proposes that the textbook compiled by the Japanese Society for History Textbook Reform places emphasis on pride in the nation, service to the nation, and obligation of national defense by giving exaggerated descriptions of international tensions, without any regard to the current world climate, and by glorifying the war, is distorting historical facts. The Japanese Society for History Textbook Reform is suspected to mobilize Japanese people and children to future wars. ' 15 The join statement remains to those who concern towards international peace:

'We must recall that the Japanese Constitution is an international declaration and an international pledge for non-aggression. Also, we must not forget this fact: with protests from many Asian countries against the suppression of the description of the Japanese "invasion" of Asia by the textbook screening panel in 1982, the Japanese government added a clause to the criteria of textbook screening that describes in "regarding the handling of historical events in modern and contemporary history involving neighboring Asian countries, due consideration shall be given from a standpoint of international understanding and cooperation." Moreover, in 1995 Mr. Murayama, the then Prime Minister expressed in his official statement apologies for "incalculable damages and pain" inflicted to Asian countries. The 1998 Japan-Korea joint declaration manifests that "it is important for both peoples, especially for the younger generation to further

15 See 'A Textbook that Treads the Path of Constitution Denial and International Isolation should not be Handed over to Japanese Children', in: http://www.ne.jp/asahi/kyokasho/net21/e 010403seimei.1.htm (Visited on 4 June 2007). 
develop an appreciation of history." These statements are a clear pledge the Japanese government made to the world. Seeing the global spirit for denial of aggressive wars, respect for equality of all peoples and the peace that has prevailed since the end of World War II, the Japanese government's thought has, until now, rightly reflected such a trend. The Japanese government has an obligation to honor this international pledge`.

Because the Japanese government had approved the textbook containing description violating the international pledges, the join statement urges the government to take appropriate action from the government. For that purpose, the join statement proposes some demands: ${ }^{16}$

1. The government has to take responsible for the selection of the controversial textbook because during the process for which the Education, Science and Technology.

2. Minister holds the authority for approval the textbook and such approval will result in the official authorization of the use of approved textbooks in classrooms.

Since politicians of the ruling parties had been active in organizing nationwide political activities to have this textbook approved and adopted and Education, Science and Technology Ministry and politicians of the ruling parties including the current Education, Science and Technology Minister that literally forced, under the name of "selfimposed control", to have deleted from existing textbooks the description of "comfort women" and the term "invasion" by applying various types of political pressure, the join statement cannot allow the government to evade a responsibility of this caliber.

3. Politicians of the ruling parties should openly cry for the cancellation of the international pledge by claiming that criticism from Asian countries is a form of intervention in domestic affairs. If the government clearly denies such a demand, Japan will surely repeat the mistake of walking the road to international isolation.

4. Do not hand over the dangerous textbook sponsored by the Japanese Society for History Textbook Reform which denies the Japanese Constitution and treads the path to international isolation. Because such textbook has passed official approval, and voices of objection have been raised about the adoption of such a text in various arenas, the join statement publicly calls for strengthening resolve against decision. By doing so, the Japanese citizens showed their good conscience to the rest of the world.

Another criticism was launched by Yoshifumi Tawara, Secretary General of the national Network of Concerned Citizens on Textbooks and Children, in website Japan in the World uploaded on 1 March 2001. Yoshifumi pointed out that while the

\footnotetext{
16 See 'A Textbook that Treads the Path of Constitution Denial and International Isolation should not be Handed over to Japanese Children', in: http://www.ne.jp/asahi/kyokasho/net21/e 010403seimei.1.htm (Visited on 4 June 2007).
} 
number of publishers producing junior high school history textbooks has increased to eight due to the entry of the right-wing the Japanese Society for History Textbook Reform into the industry, many out of the seven present history textbook publishers which have submitted the manuscripts to the ministry's screening panel have cut back considerably in terms of the content on modern history. Yoshifumi gave a more critical criticisms concerning the changing contain of the textbook in the screening process maintained by the Ministry of Education. The detailed Yoshifumi's criticism related to the deletion of reference to 'Comfort Women' and the battle of Okinawa, euphemism concerning the 'Nanjing Massacre' and Japanese invasion/ aggression into Asia, and the strategy of the triple scorched. ${ }^{17}$

Reactions and protests against the Japanese history textbook surely not only came from Japanese people but also from outside, especially China and Korea. The Chinese government and people were very angry and dissatisfied with new history textbooks that had been approved by the Japanese government and would be taught for the school year of 2002. Chinese government addressed the right-wing Japanese scholars masterminded the textbook. Foreign Ministry spokesman Zhu Banzao warned that the Chinese people would not accept the interpretation of wartime events put forth by the new textbook. ${ }^{18}$

Masalski also points out that the use of the controversial Japanese textbook also raised the severe protest and angry in Korea. In preparing to celebrate it's Liberation Day (from the Japanese) on August 15, angry Koreans continued to stage anti-Japan protests ignited by the new Japanese "textbooks that allegedly gloss over atrocities by Japanese soldiers during World War II. ${ }^{19}$ The situation became increasingly tens when the Japanese Minister Junichiro Koizumi remained to visit Yasukuni Shrine in Tokyo as a respect to Japanese military who died in the World War II, including war crimes. ${ }^{20}$ Before that, Republic of South Korea had recalled contemporarily her ambassador, Choi Sang-ryong from Tokyo in 9 April 2001 as a part of serious protest. ${ }^{21}$ Besides, Korea also inten-ded to embargo Japanese products. ${ }^{22}$ But Japanese government refused to revise the controversial textbooks Besides, Korea also inten-ded to

\footnotetext{
${ }^{17}$ For the complete criticisms see Yoshifumi Tawara, 'Junior High School History Textbooks: Whither 'Comfort Women' and the Nanking Massacre'? in: http://www.iwanami.co.jp/jpworld/text/textbook01.html (Visited on 6 June 2007).

18 Kathleen Woods Masalski, 'Examining the Japanese History Textbook Controversies', in: http://www.indiana.edu/ japan/Digests/textbook.html (Visited on 6 June 2007).

${ }^{19}$ Masalski, 'Examining the Japanese History Textbook Controversies', in: http://www.indiana.edu/ japan/Digests/textbook.html (Visited on 6 June 2007).

20 See for example 'Potong Jari Massal untuk Protes Koizumi', in: Suara Merdeka (14 Agustus 2001).

21 See 'Heboh Buku Teks Sejarah Jepang', in: http://www.kompas.com/kompas-cetak/ 0104/19/UTAMA/hebo01.htm

22 See '30 SMP Jepang Pilih Buku Sejarah Bermasalah', in: http://www.kompas. com/kompascetak/0107/14/In/smpj02.htm
} 
revise the controversial textbooks since it had no authority to do such kind action. According to the government, Japan applies democratic system in composing school textbooks. ${ }^{23}$

Again, controversy on Japanese history textbook emerged in 2005. It closely linked with the fact that the Japanese Ministry of Education approved new edition of history textbooks which also gave raise a controversy in 2001. Again, based on the protests, these textbook narrowed and even hided the atrocities and Japanese forced prostitutions of during the aggression especially in China and Korea. Korean Ministry of Foreign Affair had proposed official protest to the Japanese government. Mass demonstration had burned Japanese flag. The same actions were also taken by Chinese government against the Japanese policy on history textbook. ${ }^{24}$ Even Chinese Ambassador to Japan Wang Yi visited Vice Foreign Minister Shotaro Yachi to protest what he described as an alteration of historical fact in the textbook, which is published by Fuso Publishing Inc. 25

An internet site, 'EastSouthWestNort' published an article entitles 'Japanese History Textbooks (2005 edition)`contai- ning some analysis on the differences between history textbook composed by Japan's Society for History Textbook Reform already 2001 edition and 2005 edition. In fact there were no fundamental changes between the two. This article gave several examples about the controversial issues. One of the examples is concerning the cause of the 1894 SinoJapanese War.

'The 2001 edition of the Japanese removes the reference that the Japanese attacked the Manchurian forces first. Instead, it used the ambiguous description: "Conflict occurred between the Japanese and Manchurian military forces, and the Sino-Japanese War began."

The proposed 2005 edition goes a step further: "The Manchurians did not want to lose their final tributary state Korea and therefore treated Japan as an enemy. Japan entered the Sino-Japanese War and the RussianJapanese War due to these international relationships." The Chinese understanding of this history was that the Sino-Japanese War had its origin in the continental policy formulated at the first Imperial Congress of Japan in 1890 where their territorial interests were directed right at the Korean peninsula and northeastern China. With these goals, Japan initiated the Sino-Japanese War. China lost, paid 200 million taels

${ }^{23}$ See News Voice of America 'Jepang Tolak Permintaan Revisi Buku Sejarah’, in: http://voanews.com/indonesian/archive/2001-07/a-2001-07-09-5-1.cfm (Visited on 8 June 2007).

${ }^{24}$ See News Voice of America 'Jepang Menyetujui Sejarah yang Kontroversial', in: http://voanews.com/indonesian/archive/2005-04/2005-04-06-voa2.cfm (Visited on 8 June 2007).

25 See Akemi Nakamura 'Ministry Screeners Approve Contentious History Texts', in: http://search.japantimes.co.jp/member/member.html?nn20050406a1.htm 
of silver in compensation and ceded Taiwan and the Pescadores Islands to Japan. At the same time, Japan invaded Korea and attempted to take over the Liaotung Peninsula too. Due to the intercession of Russia, Germany and France, the Manchurian government paid Japan 300 million taels of silver to 'reclaim' Liaotung . ${ }^{26}$

Criticisms also expressed by The Children and Textbook Japan Network 21 on 26 August 2005 through its on-lined publication entitles 'Statement against Fusho-sa History Textbooks Adopted by the Tokyo Metropolitan School Board'. The criticisms was actually not directly addressed to Fusho-sa textbooks (which were published under the direction of the Japanese Society for History Textbook Reform (Tsukuru-kai), but to the Tokyo Metropolitan School Board who adopted the textbooks which since 2001 had been protested by many parties both domestically and internationally. In the end of the statement, the Children and Textbook Japan Network 21 proposed some recommendation:

1. To rescind the decision to adopt Fuso-sha textbooks for the new junior-senior high school and to open discussions about the issue all over again. The Tokyo Metropolitan School Board should base its decision upon the opinions of a wide group of Tokyo citizens, teachers, parents, and educational leaders who have expressed their deep reservations about these textbooks.

2. To open the records of the discussions held at the previous assembly meeting up to the time when the decision to adopt was made. The next discussion should be open to the public. ${ }^{27}$

Again, although ware criticisms from so many parties both domestically and internationally, the Japanese government remained to stand on their own feed. The government does not want to revise the controversial history textbooks. The government states that the authorization of textbooks does not mean the consolidation of the governmental perspective of history. The examination of whether a textbook is available for school is done by a thirdparty institution. This is part of freedom of speech and freedom of thoughts prevails in Japan. According to the government, Japan does not have national history textbook. ${ }^{28}$

During the 2005 'controversial season', the Japanese government was more open in response to the criticisms. The government did not only propose her stand not to use her authoritarian power to revise the controversial history textbooks and gave answers to every question asked by journalists or whoever. But, the demand that had been proposed by

26 See 'Japanese History Textbooks (2005 edition)', in: http://www.zonaeuropa.com/20050328_2.htm (Visited on 8 June 2007).

27 See Children and Textbook Japan Network 21, 'Statement against Fusho-sa History Textbooks Adopted by the Tokyo Metropolitan School Board' http://www.ne.jp/asahi/kyokasho/net21/statement040826.htm

28 See http://www.mofa.go.jp/announce/press/2005/4/0405.htm\#7 (Visited on 25 April 2007) 
the Children and Textbook Japan Network 21 has not been materialized by the government. Possibly, such kind of procedure is out of state regulation related to history textbooks screening. Thus, that is a matter of Japanese parliament goodwill to review regulation concerned. What is really different with the 2001 controversy is that the government (supported by Ministry of Foreign Affairs) tries to cooperate with one of the most popular internet-based interactive journal in Japan, Japan Echo, to translate and publish (at internet) multilingual translation (in English, Korean, and Chinese) of the MEXT(popular abbreviation of Ministry of Education, Culture, Sports, Science and Technology) approved middle school history textbooks.

The publication of the translations is aimed at presenting in-depth information to researchers and other people who need a deeper understanding of Japan's school textbooks especially for those who do not use Japanese as a spoken language. The textbook translations have been commissioned by the Ministry of Foreign Affairs for informing the textbook accurately and directly to all people around the world. The translated material comes from all eight of the Japanese history books approved for the 2006 school year and focused on the early modern period and the modern age which frequently become the source of controversy.
Because this project is still in progress, the site will be frequently updated in line with the development of translation results. It important to state here that by making the material available to abroad international audience, The Japan Echo Inc. hope there will be boost mutual recognition of the various historical views held throughout the nations of Asia. ${ }^{29}$

\section{Current Indonesian Case}

The latest controversy on school history textbook in Indonesia relates with the decision of the Attorney General of the Republic of Indonesia of5 March 2007 to ban the use of several kinds of school history textbooks which do not add the term 'PKI' in writing G $30 \mathrm{~S}$ (Gerakan 30 September). This controversy has actually been turned up since the end of 2005 when the Minister of National Education, Bambang Sudibyo banned the use of school history textbooks benefiting competence standard of history subject which referred to Curriculum 2004. The Minister said that this decision was based on the ongoing public discourses viewing the standard competence of Curriculum 2004 as not fully objective in describing modern Indonesia history. He said that the PKI Revolt of Madiun in 1948 was not included in the textbook. In case of the G $30 \mathrm{~S} 1965$ uprising, PKI was not mentioned as the master minder. In the meantime, the revolt of PRRI/PERMESRA and DI/TII were explicitly included. The

29 Japan Echo, 'Multilingual Translation of MEXT-approved Middle School History Textbook', in: http://www.jekaleidoscope.jp./(Visited on 9 June 2007). 
government then urged the Badan Standar Nasional Pendidikan to reformulate the competence standard of history subject in the school curriculum especially in connection with the involvement of PKI in various revolts against the state. ${ }^{30}$

The policy of the Minister of National Education had stimulated controversies in the society. In one hand, a number of Indonesian people still defended to add the term PKI in mentioning the revolt of G $30 \mathrm{~S}$ (it becomes G $30 \mathrm{~S} / \mathrm{PKI}$ ). On the other hand, part of Indonesian people insisted to remove the word PKI from the term G $30 \mathrm{~S} / \mathrm{PKI}$. Even the controversies had been colored by various mass demonstrations especially those done by certain social elements who protested the removal of the word PKI from the term G 30 S. They accused Curriculum 2004 had been benefited by the pro-PKI elements in the society to clean up the involvement of PKI in the dark period of Indonesian history. 31

Those who wanted to remove the word PKI from the term of G 30 $\mathrm{S} / \mathrm{PKI}$ argued that the tragedy is being investigated by historians. In fact, there are many theories and versions suggested by both Indonesian and foreign researchers concerning the master minder of the tragedy. ${ }^{32}$ Besides, the members and sympathizer of the PKI and those who become the victim of the military operation during the post tragedy did not agree with the addition of the word PKI in the term G $30 \mathrm{~S}$. Accusing PKI as the master minder of the revolt of $\mathrm{G} 30 \mathrm{~S}$ is considered as manipulation of historical fact. ${ }^{33} \mathrm{~A}$ historian from LIPI (Lembaga Ilmu Pengetahuan Indonesia, Aswi Warman Adam, urged to carry out a 'straightening of history'. ${ }^{34}$

The controversy has caused the history teaching at school is experiencing a dilemma weather history subject gives teaching materials without censoring or it only gives selected historical events which has been burdened by a certain moral values and political massages to the students. In this connection, the teachers have to face difficulties in teaching history subject especially in connection with the tragedies of Madiun and G 30 S 1965.35 The pupils are also facing the same difficulties in distinguishing teaching materials educated by the teachers and histori-

30 Lihat misalnya 'Buku Sejarah Kurikulum 2004 Dilarang', http://www.suaramerdeka. com/cybernews/harian/0506/27/ nas15.htm. Dikunjungi tanggal 16 Maret 2006.

31 Lihat 'Demo Penghapusan Sejarah PKI Warnai Hardiknas di Grahadi', www.mediaindo. co.id/berita.asp?id=64033. Dikunjungi tanggal 16 Maret 2006.

32 Tim ISAI, Bayang-bayang PKI (Jakarta: Institut Studi Arus Informasi, 1995), hlm. 37-38. Lihat juga Asvi Warman Adam, 'Kontrol Sejarah Semasa Pemerintahan Suharto', makalah disampaiakn pada Seminar Pra-Kipnas: Memandang Tragedi Nasional 1965 Secara Jernih. Serpong: 8 September 1990, hlm. 6.

33 Imam Soedjono, Yang Berlawan: Membongkar Tabir Pemalsuan Sejarah PKI (Yogyakarta: Resist Book, 2006), hlm. v.

34 Lihat Asvi Warman Adam, Pelurusan Sejarah Indonesia (Yogyakarta: TriDE, 2004).

35 Lihat Suara Pembaruan, 30 Juni 2005. 
cal facts exposed in monographs which are freely published. In this connection, the position of teacher is very important to give 'enlightenment' to the students.

\section{Seeing to the Field: Education History in Practice in Japan}

This part intends to look at further about the discourse of Japanese textbook controversy on the level of implementation (history teaching at school). It relates with the question of how history teacher teaches controversial history teaching materials such as those of Nanking tragedy, Japanese aggression during the World War I and II, comfort women, and the Greater East Asia War. ${ }^{36}$

The informant remains usingthe term 'Nanking massacre'/ Nankin daigyakusatsu (南京大虛殺) when describing historical events related to Nankling tragedy during the Sino - Japan war in 1937 although the several textbooks use the term 'Nanking incident' / Nankin jiken (南京事件). It seems that principally still has autonomy to express their opinion on a certain historical event and teaching methods they use. Besides, the teacher also has broader information about controversial historical events including Nanking massacre. The teacher also teaches several versions concerning this event such as Chinese version which proposes that the number of victim of Nankin massacre were about 300.000, while Japanese version proposes that the number of victim is still in debate. This means that the teacher does not treat textbook as the only sources of the truth. By explaining the versions, the teacher intends to cultivate student critical attitude leading to the capability for drawing a proportional conclusion concerning teaching mate rials given by the teacher.

Respondent uses the term 'invasion' (武力監視, buryoku kanshi) in spite of 'advancement' (寝室, zenshin) for referring the controversy on Japanese expansion to other Asian countries before and during the World War I and II. It is in line with the demand of China and Korea. The respondent is aware of this event in historical context. During that time, many industrial countries competed each other to colonize other countries. All of them wanted to show who was the strongest. Good and bad were not the main considerations.

In connection with the controversy on 'comfort women' (従 軍慰安婦, jūgun-ianfu) during the World War II, it is true that some lower secondary schools do not give this teching material to the student. Korea and China allege Japan to hide historical facts. But the the teacher has their own reasons. It is very difficult for the teacher to describe historical fact relating to women who were sent by Japanese authority to batlle ground for fulfilling sexual needs of the Japanese military personnels at the 
level of lower secondary school. They are viewed as too young for getting explanation about this sexual cruelty. But this teaching materials are given to the students of upper secondary school.

Using the term 'The Greater East Asia War' /Dai Toa Senso is also one of the controversies in explaining World War II in Asia. In this mater the respondent is consis tent to use the term 'Asia Pacific War' instead of the Greater East Asia War. The respondent argues that the term Great East Asia War was propaganda of Japanese military government to win the war against the Western colonialists and to get supports from indigenous people. The respondent proposes people. The respondent proposes that the war motivated by Japanese economic condition in connection with its industrial development, expansion to Chinese territory, and Western colonialists embargo. The respondent hopes that in the future, the writing of Japanese history should consider suggestion from China and Korea in connection with controversial issues.

\section{Concluding Remarks: History Teaching and State Interest}

This paper does not intend to trace the master minder of the socalled falsification, distortion, and euphemism of historical facts both in Japan and Indonesia. It is not surprising that the state or government has interest to involve in coloring or even deciding the history textbook for school children. This can possibly be seen as the responsibility of the government in educating the young generation in order to be a good citizen. It is strongly assumed that the state will be encouraged if it has good citizen and 'loyal to the state'. It is understandable, therefore, that most government tends to interfere to history textbook writing. This indicates that history lesson is very important for civic education.

In the 'National Curriculum Standards Reform for Kindergarten, Elementary School, Lower and Upper Secondary School and Schools for the Visually Disabled, the Hearing Impaired and the Otherwise Disabled, the Hearing Impaired and the Otherwise Disabled, the Japanese government stresses that: ${ }^{37}$

'History classes should help students respect Japanese culture and tradition and deepen their understanding and love of its history. Historical events and phenomena taught at elementary school will be selected more carefully, and the focus of history classes will be the learning of achievements by historical figures and typical cultural properties. In history classes at lower secondary school, students will study Japanese history together with world history as background knowledge. Japanese history will be shown in large sections, so that students can grasp the major

\footnotetext{
37 The Curriculum Council, 'Synopsis of the Report National Curriculum Standards Reform for Kindergarten, Elementary School, Lower and Upper secondary School and Schools for the Visually Disabled, the Hearing Impaired and the Otherwise Disabled', in: http://www.mext.go. jp/english/news/1998/07/980712.htm
} 
flow of the history. The students will also be expected to view things from different angles by learning how to study and examine history. Considering the consistency with lower secondary schools, upper secondary schools will help students deepen their understanding of Japanese and world history and develop their ability to think from a historical point of view.'

It is very clear that the history education has heavy burden to help student in cultivating 'respect to the Japanese culture and tradition and deepen their understanding and love of its history`. It is also understandable if the government also feels to have responsibility to guarantee that such kind of objective can be successfully achieved. This proves that history subject has significant role in present and future life of students. It is in line with Dilthey opinion that history can give answer about the actual question concerning present reality. ${ }^{38}$ The problem is actually stemmed from weather history education is given by selecting only for a 'beautiful` events or all events are useful for acquiring lessons from history. It is important to stress here that if the history will be benefited as a lesson, all historical facts regardless victory or defeat, rise or fall, proud or disgraceful will give certain lesson to the students. These historical facts will give the same wisdoms. The victorious and proud events will give spirit to keep it improving. On the contrary, defeating and disgraceful events can give wisdom of how to make the future better. One of the most important things is that the student should be given the nature of studying history a better future life. Leaning history for students is not for past itself but for a better recent or even future life. In this connection, it is not necessary for the government, publishers, or whoever to distort, falsify, and euphemize historical facts for the interest of student learning.

38 Raymond Boudeon \& Mohamed Cherkaoui (eds), Central Currents in Social Theory: The Root of Sociological Theory 1700-1920, Vol. IV (London: Sage, 2000), 323. 
152|Agastya Vol. 01 No. 02 Juli 2011 